http://dx.doi.org/10.18778/1644-857X.17.02.16

\title{
Sprawozdanie z Jubileuszu 70-lecia urodzin profesora Andrzeja Macieja Brzezińskiego Lódź, 11 czerwca 2018 r.
}

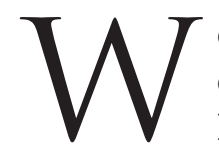

dniu 11 czerwca 2018 r. w Pałacu Biedermanna w Łodzi odbył się Jubileusz 70-lecia prof. dr. hab. Andrzeja Macieja Brzezińskiego, połączony $z$ wręczeniem Jubilatowi pracy zbiorowej pt. Politycy, dyplomaci i żotnierze. Studia i szkice z dziejów stosunków międzynarodowych $w$ XX i XXI wieku. Księga pamiątkowa, która ukazała się nakładem Wydawnictwa Uniwersytetu Łódzkiego, została zredagowana przez uczniów i współpracowników Profesora: prof. nadzw. dr. hab. Dariusza Jeziornego, prof. nadzw. dr. hab. Sławomira M. Nowinowskiego oraz prof. nadzw. dr. hab. Radosława Pawła Żurawskiego vel Grajewskiego' ${ }^{1}$. W uroczystości tej, zorganizowanej przez Katedrę Historii Powszechnej Najnowszej UŁ, uczestniczyli przedstawiciele władz Uniwersytetu Łódzkiego - Jego Magnificencję Rektora UŁ, prof. dr. hab. Antoniego Różalskiego, reprezentował prof. dr hab. Wiesław Puś, władz Wydziału Filozoficzno-Historycznego - Kolegium Dziekańskie w składzie prof. nadzw. $\mathrm{dr}$ hab. Marek Gensler, prof. nadzw. dr hab. Aneta Pawłowska oraz dr Andrzej Kompa, dyrekcji Instytutu Historii - prof. nadzw. dr hab. Dariusz Jeziorny oraz prof. nadzw. dr hab. Anna Kowalska-Pietrzak, Wydawnictwa UŁ, pracownicy tych instytucji, przyjaciele i uczniowie oraz rodzina prof. A.M. Brzezińskiego.

Spotkanie otworzył dyrektor Instytutu Historii, prof. D. Jeziorny, który przywitał dostojnego Jubilata $z$ małżonka, zaproszonych gości oraz wszystkich zgromadzonych na sali i poprosił o zabranie głosu prof. W. Pusia. Zauważył on, że $z$ prof. A.M. Brzezińskim koleguja

${ }^{1}$ Politycy, dyplomaci i żołnierze. Studia i szkice z dziejów stosunków międzynarodowych w XX $i$ XXI wieku ofiarowane Profesorowi Andrzejowi Maciejowi Brzezinskiemu $w$ 70. rocznicę urodzin, red. D. Jeziorny, S.M. Nowinowski, R.P. Żurawski vel Grajewski, Łódź 2017. 
się już 48 lat, a poznali się, gdy Jubilat był studentem drugiego roku historii, a przyszły rektor pracował jako asystent-stażysta. Występujac w imieniu Rektora, prof. Puś podkreślił, że chce podziękować za lata pracy i za wszystkie osiagnięcia prof. Brzezińskiego, np. za nagrodę Ministerstwa Spraw Zagranicznych za ostatnią książkę o Oskarze Haleckim. Zauważył ponadto, że Jubilat jest osobowościa szczególną nie tylko w Instytucie Historii, lecz także całej uczelni. Szybko pokonał kolejne szczeble kariery naukowej, rozpoczynając od doktoratu w wieku 29 lat i uzyskując profesurę 20 lat później. Od 1993 r. stał na czele zakładu, a następnie katedry, w której udało mu się stworzyć niezwykle silny zespół naukowy. Profesor W. Puś odnotował, że naukowcy, którzy odchodzą na emeryturę, w dalszym ciagu są częścią wspólnoty uniwersyteckiej, rodziny akademickiej. Dlatego też zachęcił Jubilata, by dalej brał udział $\mathrm{w}$ badaniach naukowych i działaniach podejmowanych w Instytucie i na Wydziale. Przypomniał także kilka wydarzeń z przeszłości. Zauważył, że pierwszą ważną nagrodę A.M. Brzeziński uzyskał już jako student trzeciego roku - w 1967 r. Wówczas w Krakowie jury, którym kierowała prof. Celina Bobińska, uznała referat Jubilata nt. teatru w czasach Stanisława Augusta Poniatowskiego za wybitny. Przedstawiciel Rektora wspominał również wspólne podróże do Warszawy $z$ prof. A.M. Brzezińskim i prof. Jerzym Grobisem na przełomie lat siedemdziesiątych i osiemdziesiątych, gdy gromadzili materiały do swoich kolejnych prac naukowych. Profesor Puś podkreślił także, że Jubilat nigdy nie aspirował do stanowisk, a Jego książki sa pisane pięknym, literackim językiem, co jest rzadkościa wśród historyków.

Po tym wystapieniu prof. D. Jeziorny poprosił obecnego kierownika Katedry Historii Powszechnej Najnowszej UŁ, prof. R.P. Żurawskiego vel Grajewskiego, o przedstawienie sylwetki naukowej prof. A.M. Brzezińskiego. Urodził się on 14 listopada 1947 r. we Włocławku. W rodzinnym mieście uczęszczał do III Liceum Ogólnokształcącego im. Marii Konopnickiej, gdzie w roku 1965 zdał egzamin dojrzałości. Skutkiem rozbudzonych w dzieciństwie zainteresowań przeszłościa było podjęcie studiów historycznych na Wydziale Filozoficzno-Historycznym UŁ. W tamtym czasie największy wpływ na Jubilata wywarli ówcześni pracownicy IH: doc. dr hab. Władysław Bortnowski, prof. dr hab. Józef Dutkiewicz, a także doc. dr Zofia Libiszowska. Praca magisterska pt. Zespoty teatralne Wojska Polskiego w latach 1943-1949, która uzyskała 


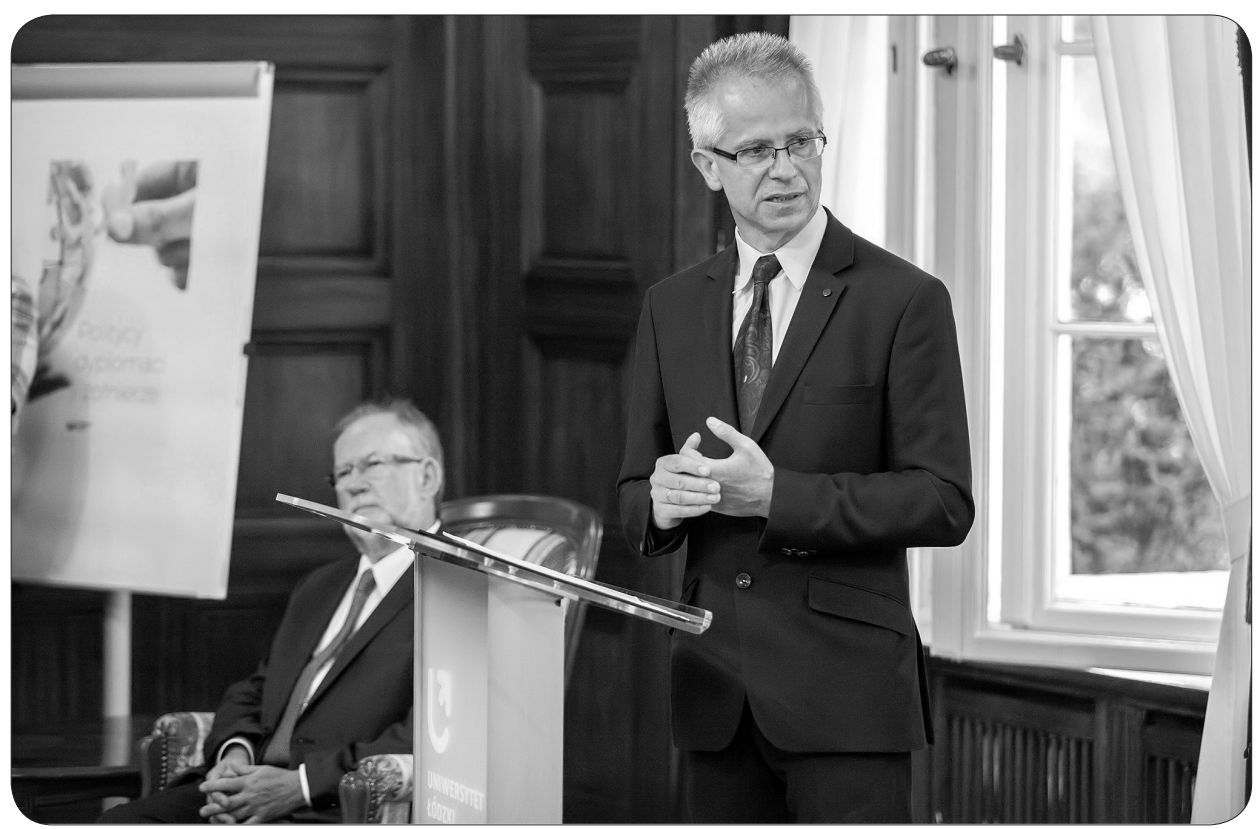

1. Jubileusz 70-lecia prof. Andrzeja Macieja Brzezińskiego (od lewej: Jubilat, prowadzący spotkanie dyrektor Instytutu Historii UŁ, prof. Dariusz Jeziorny). Fot. B. Kałużny

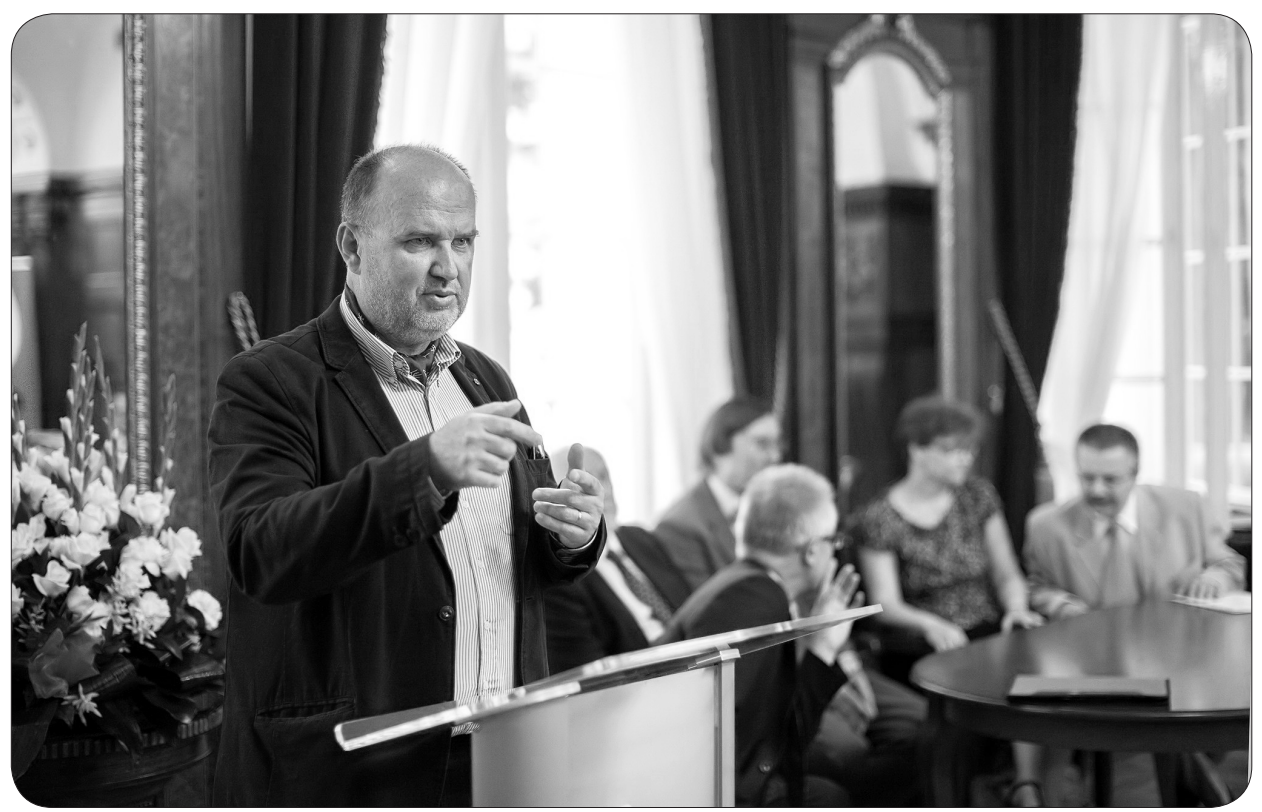

2. Przemówienie prof. Sławomira M. Nowinowskiego, występującego w imieniu uczniów Jubilata. Fot. B. Kałużny 


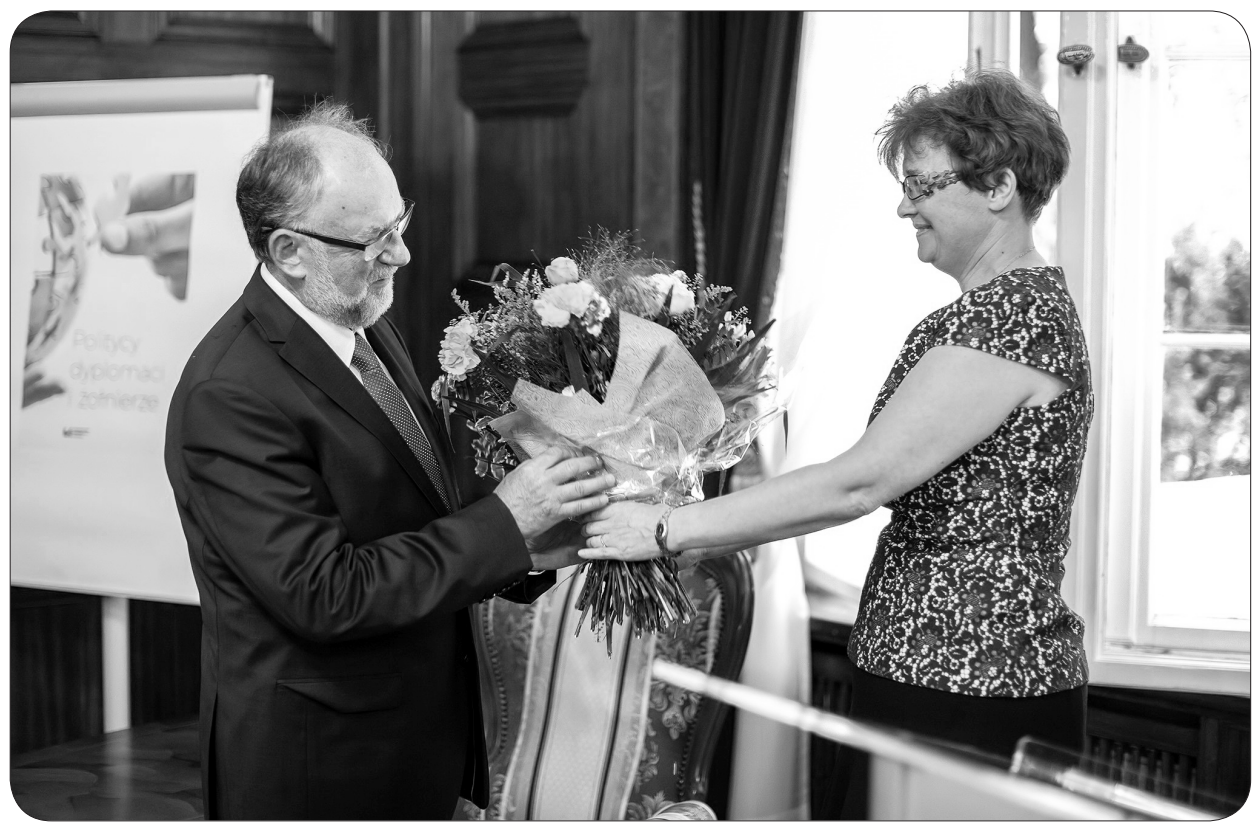

3. Wręczenie kwiatów Jubilatowi w imieniu dyrekcji i pracowników Instytutu Historii UŁ przez prof. Annę Kowalską-Pietrzak. Fot. B. Kałużny

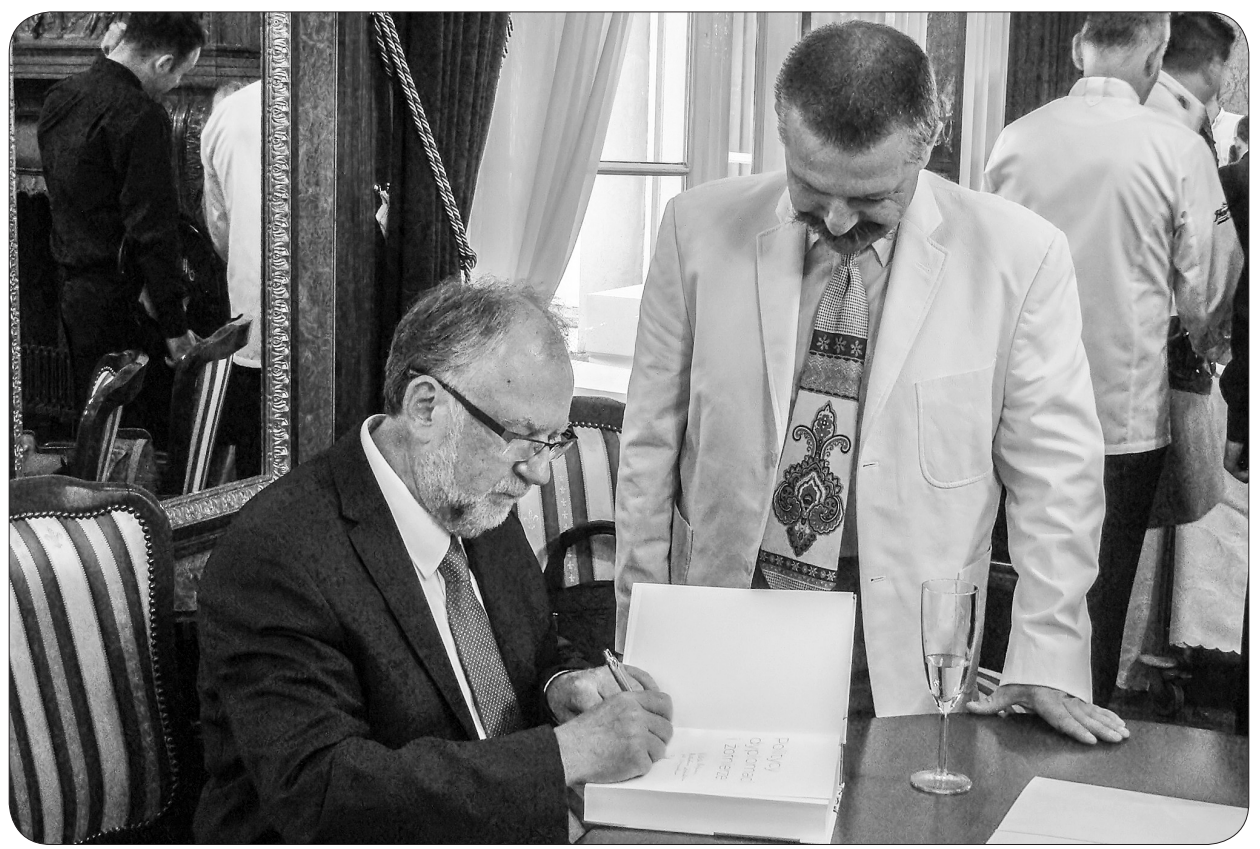

4. Dedykacja prof. A.M. Brzezińskiego w księdze pamiątkowej dla prof. Przemysława Piotra Żurawskiego vel Grajewskiego. Fot. S.L. Szczesio 
nagrodę I stopnia w Konkursie im. Aleksandra Zawadzkiego, otworzyła A.M. Brzezińskiemu drogę do kariery naukowej. W roku 1970 został asystentem w Zakładzie Historii Powszechnej Nowożytnej i Najnowszej UŁ, a w latach 1974-1975 odbył staż naukowy na Uniwersytecie im. Michaiła W. Łomonosowa w Moskwie. Przygotował wówczas, pod kierunkiem doc. dr. Waldemara Michowicza, dysertacje pt. Sprawa porozumienia angielsko-rosyjskiego $w$ latach 1903-1907, która została opublikowana w skróconej wersji ${ }^{2}$. $\mathrm{Na}$ jej podstawie uzyskał w dniu 11 listopada 1976 r. stopień doktora nauk humanistycznych w zakresie historii. Od awansu na stanowisko adiunkta w 1977 r. w centrum zainteresowań ówczesnego doktora znalazły się kwestie bezpieczeństwa i rozbrojenia w polityce zagranicznej III Republiki. Owocem tych badań i kwerend w archiwach polskich i francuskich były liczne artykuły i trzy książki: Dyplomacja francuska wobec Konferencji Rozbrojeniowej $w$ Genewie (2 II 1932 - 31 V 1937) ${ }^{3}$, Zagadnienie bezpieczeństwa zbiorowego $w$ Europie $w$ polityce zagranicznej Francji (1919-1939) oraz Warszawa-Paryż-Genewa. Sojusz polsko-francuski a problem rozbrojenia $w$ dwudziestoleciu międzywojennym (1919-1937)5. Pierwsza $z$ wymienionych stała się podstawą do nadania 21 maja $1987 \mathrm{r}$. stopnia doktora habilitowanego nauk humanistycznych w zakresie historii. W dniu 1 czerwca 1988 r. A.M. Brzeziński został docentem, niemal dokładnie półtora roku później profesorem nadzwyczajnym UŁ, a tytuł profesora nauk humanistycznych prezydent Rzeczpospolitej Polskiej nadał mu 16 grudnia 1996 r. W latach 1993-1997 kierował Zakładem Historii Powszechnej Najnowszej UŁ, następnie Katedra Historii Powszechnej Najnowszej UŁ (od 1 października 1997 do 30 września 2016 r.). Warto przypomnieć także, że pełnił funkcje zastępcy redaktora (1992-1996) i redaktora naczelnego serii Folia Historica wydawnictwa „Acta Universitatis Lodziensis" (1997-1999). Był ponadto członkiem Łódzkiego Towarzystwa Naukowego (1989-2008), Komisji Ekspertów Ministerstwa Edukacji

2 A.M. Brzeziński, Sprawa porozumienia angielsko-rosyjskiego $w$ latach 1903-1907, Łódź 1979.

${ }^{3}$ I d e m, Dyplomacja francuska wobec Konferencji Rozbrojeniowej $w$ Genewie (2 II 1932 - 31 V 1937), Łódź 1987.

${ }^{4}$ I d e m, Zagadnienie bezpieczeństwa zbiorowego $w$ Europie $w$ polityce zagranicznej Francji 1919-1939, Łódź 1992.

5 I d e m, Warszawa-Paryż-Genewa. Sojusz polsko-francuski a problem rozbrojenia $w$ dwudziestoleciu międzywojennym (1919-1937), Łódź 1996. 
Narodowej (1992-1994), Komisji Badań nad Pokojem Oddziału Polskiej Akademii Nauk w Łodzi (1999-2006), Komisji Historii Stosunków Międzynarodowych Komitetu Nauk Historycznych Polskiej Akademii Nauk (2000-2002) oraz Komitetu Nauk Historycznych Polskiej Akademii Nauk (2002-2006). Od 2001 r. zasiada w Radzie Programowej łódzkiego periodyku „Przegląd Nauk Historycznych".

Mimo zaangażowania w prace organizacyjne Profesor kontynuował swe badania, odbywając kolejne staże, misje profesorskie oraz kwerendy: w Paryżu - w 1989 i 1999 r., w Oslo - w 1997 r., w Genewie - w 1998 r. Pod koniec lat dziewięćdziesiatych XX w. ukazała się książka będąca owocem studiów nad dyplomacją polską podczas II wojny światowej ${ }^{6}$. Wkrótce prof. A.M. Brzeziński rozpoczął badania nad wkładem polskich intelektualistów w rozwój współpracy międzynarodowej w okresie międzywojennym, analizujac go w licznych artykułach oraz w dwóch źródłowych monografiach ${ }^{7}$. Warto także wspomnieć o cieszących się duża popularnością syntezach dziejów Monako oraz Grecji w wieku XX .

Pod kierunkiem Profesora powstało przeszło 150 prac magisterskich i licencjackich, wypromował on także 13 doktorów. Wielokrotnie występował $\mathrm{w}$ roli recenzenta $\mathrm{w}$ przewodach doktorskich i habilitacyjnych. Za swe dokonania naukowe prof. A.M. Brzeziński był nagradzany, otrzymał m.in. Medal Komisji Edukacji Narodowej (1994), Złoty Krzyż Zasługi (2000), Nagrodę Ministra Nauki, Szkolnictwa Wyższego i Techniki (1977), Nagrodę Ministra Edukacji Narodowej (1988). Jego ostatnia monografia, Oskar Halecki a Liga Narodów. Poglady i działalność, została wyróżniona w Konkursie na Najlepszą Książkę Akademicką w Roku 2017 oraz w Konkursie Historycznym Ministra Spraw Zagranicznych 2017 w kategorii „Najlepsza publikacja w języku polskim z zakresu historii pol-

${ }^{6}$ I d e m, Kwestia powojennej organizacji bezpieczeństwa $w$ polityce zagranicznej rząu RP na uchodźstwie 1939-1945, Łódź 1999.

7 I d e m, Polska Komisja Międzynarodowej Współpracy Intelektualnej (1924 1939), Łódź 2001; i d e m, Oskar Halecki a Liga Narodów. Poglądy i działalność, Łódź 2016.

${ }^{8}$ I d e m, Historia Monako, [w:] Historia małych krajów Europy. Andora, Liechtenstein, Luksemburg, Malta, Monako, San Marino, red. J. Laptos, Wrocław-Warszawa-Kraków 2002; i d e m, Historia Monako, [w:] Historia małych krajów Europy. Andora, Liechtenstein, Luksemburg, Malta, Monako, San Marino, red. J. Laptos, wyd. 2 popr. i uzup., Wrocław-Warszawa-Kraków 2007; i d e m, Grecja, Warszawa 2002 (seria: Historia Państw Świata w XX Wieku). 
skiej dyplomacji". Ponadto Jubilat był siedmiokrotnym laureatem indywidualnych i zespołowych nagród Rektora UŁ (1992, 1997, 1998, 2000, 2002, 2003, 2017).

Kolejną osobą, która zabrała głos podczas uroczystości, był prof. M. Gensler, prodziekan Wydziału Filozoficzno-Historycznego UŁ. Stwierdził on, że Jubilat może śmiało o sobie powiedzieć, że jest osobą spełniona akademicko, nie tylko dzięki swoim osiągnięciom i karierze, lecz także olbrzymiej radości oglądania sukcesów własnych uczniów oraz przekonaniu, że zostawia katedrę w bezpiecznych rękach swoich następców. Profesor Gensler podkreślił także, że prof. Brzeziński tworzył historię UŁ, jak również Wydziału, i jest wzorem do naśladowania.

Następnie prof. A. Kowalska-Pietrzak w imieniu dyrekcji oraz pracowników IH UŁ wręczyła bukiet kwiatów i złożyła gratulacje Jubilatowi, życząc realizacji wszystkich założonych planów, spełnienia marzeń i wielu kolejnych pięknych jubileuszy.

Po niej głos w imieniu uczniów Profesora zabrał prof. S.M. Nowinowski. Rozpoczął w sposób anegdotyczny od stwierdzenia, że występuje jako drugi wypromowany doktor (pierwszym był prof. R.P. Żurawski vel Grajewski), ale pierwszy asystent. Gdy tuż po jego zatrudnieniu prof. A.M. Brzeziński wyjechał do Stanów Zjednoczonych, usłyszał o sobie stwierdzenie, że jest "asystentem profesora, którego nie ma". Profesor Nowinowski w swoim wystapieniu podjął się opisania Jubilata jako „szefa”, a termin ten nawiazywał do określenia używanego w MSZ, gdy wiceministrem został Józef Beck. Według wieloletniego współpracownika prof. A.M. Brzezińskiego wypracował on model szefa rzadko spotykany w IH UŁ i w świecie akademickim. Nie uważał, że feudalizm to najlepsza forma organizacji życia uczelnianego. Imponował rozległą wiedzą, znajomością świata, języków, dyscypliną pracy i słowa $\mathrm{w}$ mowie oraz w piśmie. Nie oczekiwał, że uczniowie będą dziedziczyć jego zainteresowania naukowe, mając równocześnie do nich zaufanie. Nie musiał ich prowadzić za rękę, lecz zawsze spieszył $z$ pomocna dłonią w razie potrzeby. Jako "szef” przypominał, że życie nie sprowadza się tylko do pracy naukowej, lecz ma szereg innych uroków. Chociaż zajmował się głównie historia powszechną, stale przypominał współpracownikom, że maja też obowiązi wobec polskiej Klio, samemu dając tego przykład.

Następnie głos zabrał przedstawiciel Wydziału Studiów Międzynarodowych i Politologicznych UŁ, prof. dr hab. Przemysław Piotr 
Żurawski vel Grajewski. Stwierdził on, że pierwszy raz zetknął się z Jubilatem jeszcze jako uczeń liceum, gdy podczas Olimpiady Historycznej był egzaminowany przez komisję, w składzie której zasiadał A.M. Brzeziński. Kolejnym wspomnieniem prof. Żurawskiego vel Grajewskiego było uczestnictwo, jako student, w 1985 r. w ćwiczeniach prowadzonych przez Profesora. Ocenił je jako niezwykle „ożywiające intelektualnie”, dające mu „iskrę intelektualna”. Trzecim elementem, który połączył te dwie osoby, było seminarium magisterskie prof. dr. hab. Waldemara Michowicza, w których A.M. Brzeziński uczestniczył jako adiunkt. Również ten czas prof. P.P. Żurawski vel Grajewski wspominał jako niezwykła przygodę. Na koniec swego wystapienia podziękował Jubilatowi za niezwykłe doświadczenie dydaktyczne $z$ czasów ćwiczeń, jak i za późniejsze doświadczenia naukowo-badawcze, gdy korzystał z licznych prac Profesora.

Kolejna osoba, która zabrała głos, była prof. nadzw. dr hab. Katarzyna Jedynakiewicz-Mróz. Na początku zauważyła, że była pierwszym adiunktem zatrudnionym przez Jubilata, chociaż nie została przez niego wypromowana. Jej mistrzem był prof. dr hab. Zbigniew Kuchowicz, a po jego śmierci promotorem rozprawy doktorskiej stał się prof. J. Grobis. Czuje się jednak uczennica prof. A.M. Brzezińskiego, gdyż jej praca habilitacyjna nie powstałaby bez Jego wsparcia. Umożliwił jej powrót do pierwotnych zainteresowań badawczych, dając wolną rękę w wyborze tematyki. Dzięki dobrej woli i otwartości Jubilata prof. Jedynakiewicz-Mróz zajęła się problematyką niemiecką i historią kultury. Podziękowała mu za to wsparcie i stwierdziła, że uważa Go za jedna z najważniejszych osób w swoim życiu.

Następnie kilka słów wypowiedział obecny dziekan Wydziału Ekonomiczno-Socjologicznego Ut, prof. dr hab. Rafał Matera. Zauważył, że chociaż nie został doktorantem Jubilata, to chciałby potwierdzić, że Jego seminarium magisterskie było jednym $z$ najlepszych w IH, stając się prawdziwa ucztą intelektualną dla studentów. $Z$ tych czasów pamięta Jubilata jako osobę bardzo otwarta na świat, rozmawiajaccego $z$ seminarzystami o podróżach. Profesor Matera przypomniał także, że po napisaniu pracy magisterskiej u prof. A.M. Brzezińskiego pragnął zostać Jego doktorantem. Jednak Jubilat zaproponował wówczas, by podjął studia doktoranckie na ekonomii, a opiekunem mógłby był prof. Janusz Skodlarski. Za tę wskazówkę i wypowiedziane wówczas słowa: „Na pewno da 
pan radę" obecny dziekan Wydziału Ekonomiczno-Socjologicznego serdecznie podziękował.

W imieniu najmłodszego pokolenia wychowanków Profesora głos zabrał dr Bartosz Kaczorowski. Przypomniał, że Jubilat przyczynił się do jego rozwoju intelektualnego jako promotor pracy magisterskiej, a w czasie recenzowania dysertacji doktorskiej okazał się znakomitym znawcą dziejów Półwyspu Iberyjskiego. Podkreślił ponadto zaangażowanie ówczesnego kierownika Katedry w zatrudnienie go na stanowisku adiunkta, mimo problemów zdrowotnych, co jest doskonałą egzemplifikacją ludzkich cech prof. A.M. Brzezińskiego.

W dalszej części spotkania nastapiło uroczyste wręczenie przez trzech współredaktorów księgi pamiątkowej Jubilatowi, która - jak zauważył prof. D. Jeziorny - jest uhonorowaniem pracy Profesora i wielkim podziękowaniem za wszystko, co zrobił. W pracy tej znalazły się artykuły ponad 40 naukowców, opisujące różne aspekty stosunków międzynarodowych od początku wieku XX aż po problemy współczesnego świata, oraz bibliografia publikacji naukowych prof. A.M. Brzezińskiego.

Wówczas głos zabrał Bohater spotkania. Rozpoczął od serdecznych podziękowań wszystkim gościom za przybycie, a także organizatorom i swojej żonie za przygotowanie tej uroczystości. Wyraził również wdzięczność redaktorom i współautorom pracy zbiorowej. Podkreślił, że szczególnie cieszy się $z$ tego, iż znalazły się w niej teksty nie tylko doświadczonych historyków, lecz także wypromowanych przez niego doktorów. $Z$ perspektywy kilkudziesięciu lat pracy zawodowej na Uniwersytecie Łódzkim Jubilat stwierdził, że miał wielkie szczęście spotykać na swej drodze wybitnych profesorów, od których mógł się wiele nauczyć i którzy początkowo nadawali kierunek badaniom naukowym. Na tej liście znaleźli się m.in. prof. prof. W. Bortnowski (promotor pracy magisterskiej), Helena Brodowska, W. Michowicz (opiekun koła naukowego w czasie, gdy A.M. Brzeziński był jego prezesem), Józef Dutkiewicz. Jubilat wspominał propozycję złożona przez prof. W. Michowicza asystentury w Zakładzie Historii Powszechnej Nowożytnej i Najnowszej UŁ. Kierował nią wówczas prof. Józef Dutkiewicz, pełniacy równocześnie funkcję dyrektora IH. To ten badacz stał się wówczas dla młodego adepta nauki niedoścignionym wzorcem, jeśli chodzi o zwięzłość i lakoniczność w słowie pisanym i mówionym. Był naukowcem o ogromnej wiedzy i doskonałym organizatorem. W tym czasie Jubi- 
lat pozostawał pod opieka naukowa prof. W. Michowicza, który został promotorem jego pracy doktorskiej, a także włączył go do swego zespołu zajmującego się problematyką bezpieczeństwa i rozbrojenia. Apogeum tej działalności stało się powołanie przy UŁ Centrum Badań nad Pokojem, którego szefem był prof. Michowicz, a sekretarzem naukowym prof. Brzeziński, oraz współpraca $z$ oddziałem łódzkim Polskiej Akademii Nauk, któremu przewodniczył wówczas prof. Jan Michalski. Jak przyznał Jubilat, już jako samodzielny pracownik naukowy miał szczęście, że chcieli $z$ nim współdziałać utalentowani studenci, $z$ których część jest obecnie pracownikami naukowymi jego Katedry. Cieszył się z każdego ich sukcesu, ich doktoratów, habilitacji, kolejnych prac ukazujących się drukiem. Daje mu to pewność, że nie musi się obecnie martwić o los Katedry, gdyż zostaje ona w dobrych rękach. Jubilat podkreślił, że w pracy uniwersyteckiej wsparcie osób najbliższych jest szczególnie ważne, a on taka pomoc ma od wielu lat i za to serdecznie dziękuje. $\mathrm{Na}$ zakończenie swego wystapienia prof. A.M. Brzeziński oświadczył, że jest to jeden $z$ najszczęśliwszych dni w jego życiu.

Wówczas prowadzący to spotkanie prof. D. Jeziorny podziękował za to bardzo osobiste i wzruszające przemówienie i rozpoczą się kolejny punkt uroczystości - wręczenie przez redaktorów księgi jubileuszowej autorom tekstów. Następnie organizatorzy zachęcili wszystkich obecnych do wpisywania się na dwóch plakatach, które będa pamiątką dla Jubilata oraz dla Katedry. Na koniec wzniesiono toast ku czci Bohatera tej uroczystości, a prof. D. Jeziorny życzył w imieniu zebranych zdrowia, niegasnacego poczucia humoru, lekkiego przekąsu oraz radości. Rozpoczą się poczęstunek, w tym jubileuszowym tortem, nastapiły gratulacje i życzenia składane na ręce dostojnego Jubilata. Była także okazja do uzyskania wpisu w księdze pamiątkowej i zrobienia pamiątkowej fotografii. Profesorowi A.M. Brzezińskiemu serdecznie gratulujemy tego jubileuszu i życzymy mu szlachetnego zdrowia, pogody ducha oraz kolejnych interesujących publikacji.

Stawomir LucJan Szczesio

UNIWERSYTET ŁÓDZKI*

* Wydział Filozoficzno-Historyczny, Instytut Historii, Katedra Historii Polski i Świata po 1945 roku, e-mail: szczesioslawomir@uni.lodz.pl. 


\section{Bibliografia}

\section{Opracowania}

Brzeziński A.M., Dyplomacja francuska wobec Konferencji Rozbrojeniowej w Genewie (2 II 1932 - 31 V 1937), Łódź 1987.

Brzeziński A.M., Grecja, Warszawa 2002 (seria: Historia Państw Świata w XX Wieku).

Brzeziński A.M., Historia Monako, [w:] Historia małych krajów Europy. Andora, Liechtenstein, Luksemburg, Malta, Monako, San Marino, red. J. Łaptos, Wrocław-Warszawa-Kraków 2002.

Brzeziński A.M., Historia Monako, [w:] Historia małych krajów Europy. Andora, Liechtenstein, Luksemburg, Malta, Monako, San Marino, red. J. Łaptos, wyd. 2 popr. i uzup., Wrocław-Warszawa-Kraków 2007.

Brzeziński A.M., Kwestia powojennej organizacji bezpieczeństwa $w$ polityce zagranicznej rządu RP na uchodźstwie 1939-1945, Łódź 1999.

Brzeziński A.M., Oskar Halecki a Liga Narodów. Poglądy i działalność, Łódź 2016.

Brzeziński A.M., Polska Komisja Międzynarodowej Wspótpracy Intelektualnej (1924-1939), Łódź 2001.

Brzeziński A.M., Sprawa porozumienia angielsko-rosyjskiego w latach 19031907, Łódź 1979.

Brzeziński A.M., Warszawa-Paryż-Genewa. Sojusz polsko-francuski a problem rozbrojenia $w$ dwudziestoleciu międzywojennym (1919-1937), Łódź 1996.

Brzeziński A.M., Zagadnienie bezpieczeństwa zbiorowego $w$ Europie $w$ polityce zagranicznej Francji 1919-1939, Łódź 1992.

Politycy, dyplomaci $i$ żotnierze. Studia $i$ szkice $z$ dziejów stosunków międzynarodowych wXX $i$ XXI wieku ofiarowane Profesorowi Andrzejowi Maciejowi Brzezińskiemu $w$ 70. rocznice urodzin, red. D. Jeziorny, S.M. Nowinowski, R.P. Żurawski vel Grajewski, Łódź 2017. 